\title{
A RETROSPECTIVE DESCRIPTIVE STUDY OF HEAD INJURY PATIENTS ADMITTED IN MY HOSPITAL, INDORE, BETWEEN 2011-2013
}

\author{
Paresh Sodhiya1, Zafar Ahmed H. Sheikh², Mukesh Sharma ${ }^{3}$, Vineet Mandrah4 \\ ${ }_{1}^{1}$ Assistant Professor, Department of Neurosurgery, MGMMC and MYH, Indore, Madhya Pradesh. \\ ${ }^{2}$ Assistant Professor, Department of Surgery, MGMMC and MYH, Indore, Madhya Pradesh. \\ 3 Senior Resident, Department of Surgery, MGMMC and MYH, Indore, Madhya Pradesh. \\ ${ }_{4}^{4}$ Resident, Department of Surgery, MGMMC and MYH, Indore, Madhya Pradesh.
}

\section{BACKGROUND}

ABSTRACT

Traumatic brain injury is an alarming and rising epidemic disease affecting the majority of population of Indore. A detailed epidemiological study was therefore much needed to analyse its impact on the health of people, availability of health resources and plan future strategies based on them.

\section{MATERIALS AND METHODS}

This is a retrospective analysis of head injury cases admitted at MYH Indore, between January 2011 and December 2013.

\section{RESULTS}

A total of 2822 cases of head Injury were admitted. 1291 patients of head injury were victims of RTA. Of these 51\% were occupants of two-wheeler, $31 \%$ were of four-wheeler and $18 \%$ were pedestrians. The head injury victims between the ages of 21 and 40 years accounted for $46.7 \%$ of all. Of the total 2822 patients of head injury, 55.5\% patients suffered from mild head injury, while $44.5 \%$ patients had moderate-to-severe head injury. $7.8 \%$ of mild head injury still needed emergency neurosurgical intervention. In comparison $71 \%$ of all patients were having moderate-to-severe head injury, did not need neurosurgical procedure.

\section{CONCLUSION}

The severity of head Injury can be reduced by enforcing existing traffic rules strictly which includes use of helmets for two wheelers, safety seat belts for four wheelers and setting speed limits. This study clearly highlights the fact that even mild head injury patients need observation and may need referral to a suitable neurosurgical centre, whereas majority of patients with moderate-to-severe head injury could also be managed at nearest urban and rural centres with ICU care setup under active supervision of neurosurgeons to optimise their management.

\section{KEYWORDS}

Head Injury, Neurotrauma.

HOW TO CITE THIS ARTICLE: Sodhiya P, Sheikh ZAH, Sharma M, et al. A retrospective descriptive study of head injury patients admitted in MY hospital, Indore, between 2011-2013. J. Evolution Med. Dent. Sci. 2018;7(15):1857-1861, DOI: $10.14260 /$ jemds/2018/419

\section{BACKGROUND}

Maharaja Yeshwantrao Hospital (MYH), Indore (MP), is a multispecialty 1200 bedded hospital. This tertiary health centre in public sector was established in 1955 and caters to the population of MP and adjacent areas of states of Gujarat, Rajasthan and Maharashtra. The nearest similar public sector tertiary centres are located in more than $200 \mathrm{~km}$ radius. This hospital alone holds the burden of Indore region including 8 districts of the surrounding area. Everyday approximately 2000 patients visit the hospital. On an average about 150 patients per day are examined as outdoor patients in the surgery department daily and 25 - 35 patients are hospitalised for indoor management.

'Financial or Other Competing Interest': None.

Submission 27-02-2018, Peer Review 11-03-2018,

Acceptance 13-03-2018, Published 09-04-2018.

Corresponding Author:

Dr. Zafar Ahmed H. Sheikh,

G1 Kasturi Apts., 12 Shankar Nagar

Saket Extension,

Indore-452018,

Madhya Pradesh.

E-mail: zafar18@gmail.com

DOI: $10.14260 /$ jemds $/ 2018 / 419$
The demographic, epidemiological and economic transition in this region has changed significantly during the last two decades.

The rapid urbanisation, industrialisation, motorisation, immigration etc. have changed the lifestyles of individuals giving rise to a plethora of problems, among which injuries top the list.

It is estimated that traumatic head injury is a major emerging epidemic affecting thousands of working population at Indore and adjacent region. A detailed epidemiological study is therefore much needed to analyse its impact on the health of people, availability of health resources and plan future strategies based on them.

\section{Aims and Objectives}

1. To analyse the epidemiology of head injury patients in tertiary referral centre of Indore MYH retrospectively between year 2011 and 2013.

2. Assessment of available resources to deal with cases of Neurotrauma and need to upgrade the facilities.

\section{MATERIALS AND METHODS}

This is a retrospective analysis of head injury cases admitted at MYH Indore between January 2011 and December 2013. 


\section{Inclusion Criteria}

All patients with diagnosis of head injury (including polytrauma with head injury) treated at MYH as inpatients within specified duration as above.

\section{Exclusion Criteria}

Patients brought dead to MYH.

\section{RESULTS}

Between Jan 2011 and Dec 2013, a total number of 24477 cases were admitted in surgery department. Out of these, 2822 were diagnosed as head injury cases. All these cases were included in the study. The details were as follows-

\begin{tabular}{|c|c|c|c|c|c|}
\hline $\begin{array}{l}\text { Sr. } \\
\text { No. }\end{array}$ & Aetiology & $\begin{array}{c}\text { Year } 2011 \\
n=793\end{array}$ & $\begin{array}{c}\text { Year } \\
2012 \\
n=901\end{array}$ & \begin{tabular}{c|} 
Year \\
2013 \\
$n=1128$ \\
\end{tabular} & $\begin{array}{c}\text { Total } \\
\mathbf{n}=2822\end{array}$ \\
\hline 1. & $\begin{array}{c}\text { Road traffic } \\
\text { accidents }\end{array}$ & $390(49.2 \%)$ & $\begin{array}{c}416 \\
(46.2 \%)\end{array}$ & $\begin{array}{c}485 \\
(43 \%)\end{array}$ & $\begin{array}{c}1291 \\
(45.7 \%)\end{array}$ \\
\hline 2. & $\begin{array}{c}\text { Fall from } \\
\text { height }\end{array}$ & $\begin{array}{c}180 \\
(22.7 \%) \\
\end{array}$ & $\begin{array}{c}230 \\
(25.5 \%) \\
\end{array}$ & $\begin{array}{c}285 \\
(25.3 \%) \\
\end{array}$ & $\begin{array}{c}695 \\
(24.6 \%) \\
\end{array}$ \\
\hline 3. & Assaults & $194(24$ & $\begin{array}{c}210 \\
(23.3 \%)\end{array}$ & $\begin{array}{c}298 \\
(26.4 \%) \\
\end{array}$ & \begin{tabular}{|c|}
702 \\
$(24.9 \%)$ \\
\end{tabular} \\
\hline 4. & $\begin{array}{l}\text { Sports } \\
\text { injury }\end{array}$ & $8(2 \%)$ & $10(1.1 \%)$ & $12(1.1 \%)$ & $\begin{array}{c}30 \\
(1.1 \%)\end{array}$ \\
\hline 5. & Others* & $21(2.6 \%)$ & $35(3.9 \%)$ & $48(4.3 \%)$ & $\begin{array}{c}104 \\
(3.7 \%)\end{array}$ \\
\hline
\end{tabular}

*Other cases: - Train accidents $=28$; fall from tree and poles $=36$; animal injuries $=40$.

\begin{tabular}{|c|c|c|c|c|}
\hline $\begin{array}{c}\text { Sr. } \\
\text { No. }\end{array}$ & $\begin{array}{c}\text { Cases } \\
\mathbf{n = 1 2 9 1}\end{array}$ & $\begin{array}{c}\text { Year 2011 } \\
\mathbf{n = 3 9 0}\end{array}$ & $\begin{array}{c}\text { Year 2012 } \\
\mathbf{n = 4 1 6}\end{array}$ & $\begin{array}{c}\text { Year 2013 } \\
\mathbf{n = 4 8 5}\end{array}$ \\
\hline 1. & $\begin{array}{c}\text { Mild head injury } \\
\text { GCS 13-15 }\end{array}$ & $\begin{array}{c}194 \\
(49.7 \%)\end{array}$ & $205(49.3)$ & $\begin{array}{c}241 \\
(49.7 \%)\end{array}$ \\
\hline 2. & $\begin{array}{c}\text { Moderate head } \\
\text { injury } \\
\text { GCS 9-12 }\end{array}$ & $\begin{array}{c}122 \\
(31.3 \%)\end{array}$ & $\begin{array}{c}135 \\
(32.5 \%)\end{array}$ & $\begin{array}{c}154 \\
(31.8 \%)\end{array}$ \\
\hline 3. & $\begin{array}{c}\text { Severe head } \\
\text { injury } \\
\text { GCS < 8 }\end{array}$ & $74(19 \%)$ & $76(18.2 \%)$ & $90(18.6 \%)$ \\
\hline \multicolumn{5}{|c|}{$\begin{array}{c}\text { Table 1 (b). Yearly distribution of RTA } \\
\text { cases according to GCS Score }\end{array}$} \\
\hline
\end{tabular}

Table 2- Age and Sex Distribution

Total number of cases- 2822

Total number of male patients- 2301 (81.53\%)

Total number of female patients- 521 (18.46\%)

\begin{tabular}{|c|c|c|c|c|c|}
\hline $\begin{array}{c}\text { Sr. } \\
\text { No. }\end{array}$ & $\begin{array}{c}\text { Age } \\
\text { Groups }\end{array}$ & $\begin{array}{c}\text { No. of Cases } \\
\mathbf{( \% )} \\
\mathbf{n = 2 8 2 2}\end{array}$ & $\begin{array}{c}\text { Males } \\
\mathbf{( \% )} \\
\mathbf{n = 2 3 0 1}\end{array}$ & $\begin{array}{c}\text { Females } \\
\mathbf{( \% )} \\
\mathbf{n = 5 2 1}\end{array}$ & $\begin{array}{c}\text { Male: } \\
\text { Female } \\
\text { Ratio }\end{array}$ \\
\hline 1. & $\begin{array}{c}\text { Upto 10 } \\
\text { years }\end{array}$ & $\begin{array}{c}390 \\
(13.8 \%)\end{array}$ & $\begin{array}{c}230 \\
(59 \%)\end{array}$ & $\begin{array}{c}160 \\
(41 \%)\end{array}$ & $1.5: 1$ \\
\hline 2. & $\begin{array}{c}11-20 \\
\text { years }\end{array}$ & $\begin{array}{c}409 \\
(14.4 \%)\end{array}$ & $\begin{array}{c}366 \\
(89.4 \%)\end{array}$ & $\begin{array}{c}43 \\
(10.6 \%)\end{array}$ & $8.5: 1$ \\
\hline 3. & $\begin{array}{c}21-30 \\
\text { years }\end{array}$ & $\begin{array}{c}711 \\
(25.2 \%)\end{array}$ & $\begin{array}{c}640 \\
(90 \%)\end{array}$ & $71(10 \%)$ & $9: 1$ \\
\hline 4. & $\begin{array}{c}31-40 \\
\text { years }\end{array}$ & $\begin{array}{c}608 \\
(21.5 \%)\end{array}$ & $\begin{array}{c}540 \\
(88.9 \%)\end{array}$ & $\begin{array}{c}68 \\
(11.1 \%)\end{array}$ & $7.9: 1$ \\
\hline 5. & $\begin{array}{c}41-50 \\
\text { years }\end{array}$ & $\begin{array}{c}348 \\
(12.3 \%)\end{array}$ & $\begin{array}{c}266 \\
(76.4 \%)\end{array}$ & $\begin{array}{c}82 \\
(23.6 \%)\end{array}$ & $3.2: 1$ \\
\hline 6. & $\begin{array}{c}51-60 \\
\text { years }\end{array}$ & $\begin{array}{c}185 \\
(6.5 \%)\end{array}$ & $\begin{array}{c}144 \\
(77.8 \%)\end{array}$ & $\begin{array}{c}41 \\
(22.2 \%)\end{array}$ & $3.6: 1$ \\
\hline 7. & $\begin{array}{c}\text { Above 60 } \\
\text { years }\end{array}$ & $\begin{array}{c}171 \\
(6.3 \%)\end{array}$ & $\begin{array}{c}115 \\
(67.2 \%)\end{array}$ & $\begin{array}{c}56 \\
(32.8 \%)\end{array}$ & $2: 1$ \\
\hline
\end{tabular}

Table 3. Causes of Head Injury in different Age Groups
Total number of cases $=2822$

\begin{tabular}{|c|c|c|c|c|c|}
\hline $\begin{array}{c}\text { Sr. } \\
\text { No. }\end{array}$ & $\begin{array}{c}\text { Age } \\
\text { Group }\end{array}$ & $\begin{array}{c}\text { RTA } \\
\mathbf{( \% )} \\
\mathbf{n = 1 2 9 1}\end{array}$ & $\begin{array}{c}\text { Fall } \\
\mathbf{( \% )} \\
\mathbf{n = 6 9 5}\end{array}$ & $\begin{array}{c}\text { Assault } \\
\mathbf{( \% )} \\
\mathbf{n = 7 0 2}\end{array}$ & $\begin{array}{c}\text { Others } \\
\mathbf{( \% )} \\
\mathbf{n = 1 3 4}\end{array}$ \\
\hline 1. & $\begin{array}{c}<10 \\
\text { years }\end{array}$ & $110(8.5 \%)$ & $\begin{array}{c}170 \\
(24.4 \%)\end{array}$ & $70(9.9 \%)$ & $\begin{array}{c}40 \\
(30.7 \%)\end{array}$ \\
\hline 2. & $\begin{array}{c}11-20 \\
\text { years }\end{array}$ & $194(15 \%)$ & $\begin{array}{c}102 \\
(14.6 \%)\end{array}$ & $49(6.9 \%)$ & $28(21 \%)$ \\
\hline 3. & $\begin{array}{c}21-30 \\
\text { years }\end{array}$ & $\begin{array}{c}368 \\
(28.5 \%)\end{array}$ & $68(9.8 \%)$ & $\begin{array}{c}262 \\
(37.3 \%)\end{array}$ & $\begin{array}{c}19 \\
(14.2 \%)\end{array}$ \\
\hline 4. & $\begin{array}{c}31-40 \\
\text { years }\end{array}$ & $296(23 \%)$ & $\begin{array}{c}203 \\
(29.2 \%)\end{array}$ & $\begin{array}{c}146 \\
(20.8 \%)\end{array}$ & $\begin{array}{c}38 \\
(28.3 \%)\end{array}$ \\
\hline 5. & $\begin{array}{c}41-50 \\
\text { years }\end{array}$ & $\begin{array}{c}136 \\
(10.5 \%)\end{array}$ & $68(9.9 \%)$ & $73(10.4 \%)$ & $\begin{array}{c}29 \\
(21.6 \%)\end{array}$ \\
\hline 6. & $\begin{array}{c}51-60 \\
\text { years }\end{array}$ & $95(7.3 \%)$ & $17(2.4 \%)$ & $24(3.4 \%)$ & $08(6 \%)$ \\
\hline 7. & Above 60 & $92(7.1 \%)$ & $67(9.6 \%)$ & $78(11.1 \%)$ & $10(7.4 \%)$ \\
\hline & Total & $\begin{array}{c}\mathbf{1 2 9 1} \\
(\mathbf{4 5 . 7 \% )}\end{array}$ & $\begin{array}{c}\mathbf{6 9 5} \\
\mathbf{( 2 4 . 6 \% )}\end{array}$ & $\begin{array}{c}\mathbf{7 0 2} \\
\mathbf{( 2 4 . 8 \% )}\end{array}$ & $\begin{array}{c}\mathbf{1 3 4} \\
\mathbf{( 4 . 7 \% )}\end{array}$ \\
\hline
\end{tabular}

Highest incidence of head injury was due to road traffic accidents followed by assault and falls. The incidence of head injury was seen due to RTA in the third decade of life, $28.5 \%$ followed by assault $37.3 \%$.

\section{Causes of Head Injury in different Age Groups}

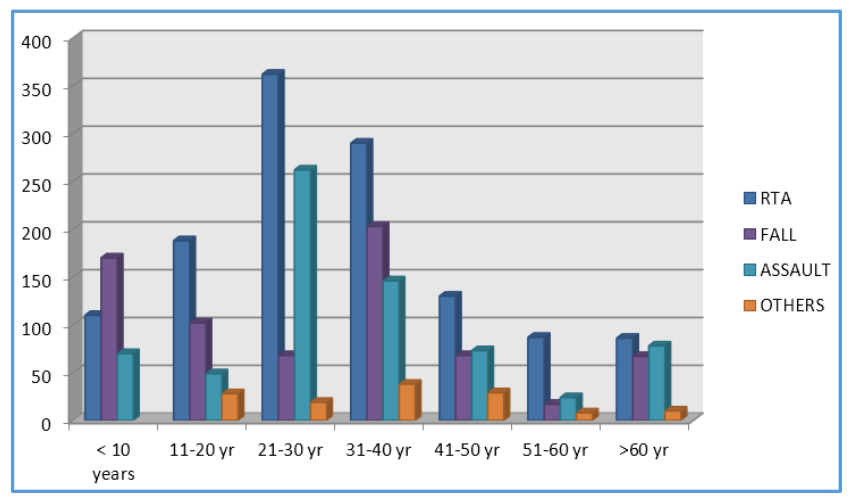

Time Interval between Injury and Admission

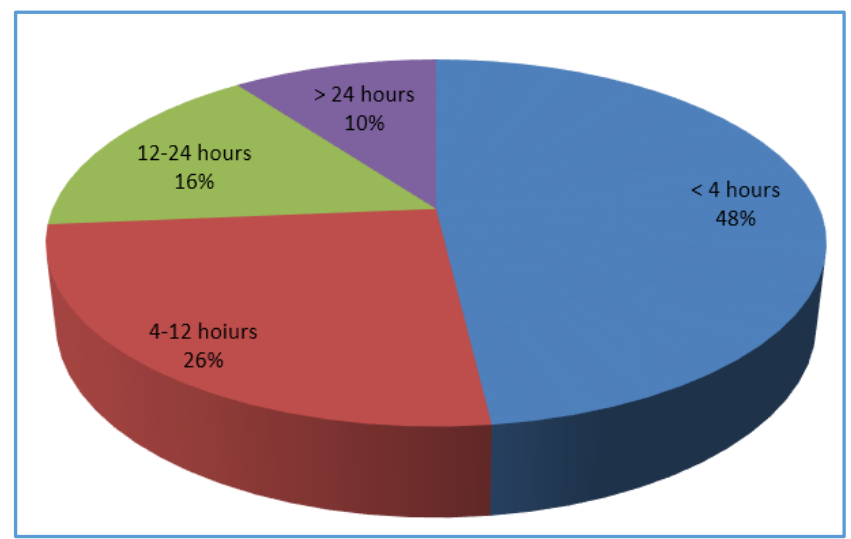

Total number of cases $=2822$

\begin{tabular}{|c|c|c|}
\hline Sr. No. & Glasgow Coma Score & Cases (n= 2822) \\
\hline 1. & Mild head injury GCS 13-15 & $1565(55.5 \%)$ \\
\hline 2. & Moderate head injury GCS $9-12$ & $413(14.6 \%)$ \\
\hline 3. & Severe head injury GCS < 8 & $844(29.9 \%)$ \\
\hline Table 4. Severity of Head Injury cases based on Glasgow \\
Coma Score \\
\hline \multicolumn{3}{|c|}{} \\
\hline
\end{tabular}


Distribution of Cases Admitted Directly or Referred from other Hospitals according to Glasgow Coma Score-

Total number of cases $=2822$

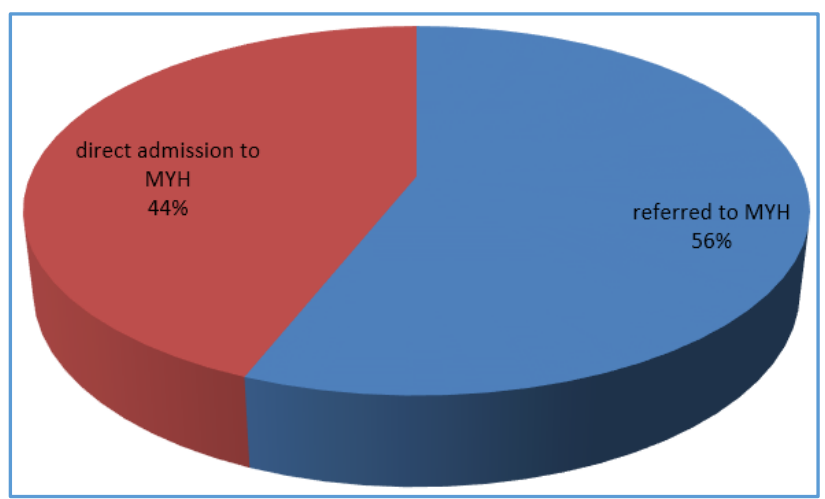

\begin{tabular}{|l|c|c|c|c|c|}
\hline $\begin{array}{l}\text { Sr. } \\
\text { No. Intoxication }\end{array}$ & $\begin{array}{c}\text { Alcohol } \\
\text { Mild Head } \\
\text { Injury } \\
\text { GCS 13-15 } \\
\mathbf{n = 1 3 6 5}\end{array}$ & $\begin{array}{c}\text { Moderate } \\
\text { Head Injury } \\
\text { GCS 9-12 } \\
\mathbf{n = 3 4 3}\end{array}$ & $\begin{array}{c}\text { Severe } \\
\text { Head } \\
\text { Injury } \\
\text { GCS }<8 \\
\mathbf{n = 7 2 4}\end{array}$ & $\begin{array}{c}\text { Total } \\
\mathbf{n = 2 4 3 2} \\
\text { (Excluding } \\
\text { First } \\
\text { Decade } \\
\text { Patients) }\end{array}$ \\
\hline 1. & Present & $\begin{array}{c}136 \\
(9.7 \%)\end{array}$ & $\begin{array}{c}73 \\
(21.3 \%)\end{array}$ & $\begin{array}{c}102 \\
(14 \%)\end{array}$ & $\begin{array}{c}311 \\
(13 \%)\end{array}$ \\
\hline \multicolumn{4}{|c|}{ Table 5. Presence of Alcohol in Head Injury Patients at the } \\
Time of Admission
\end{tabular}

Chart depicting year wise breakup of the neurosurgical procedures done in 479 patients.

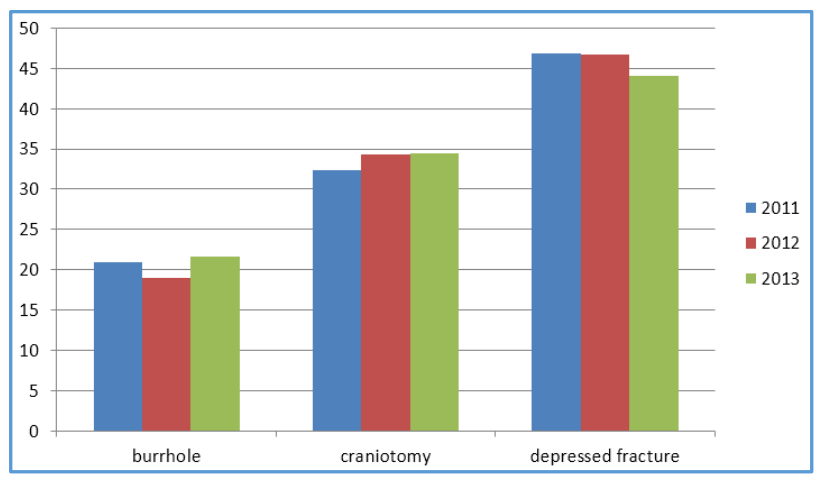

Total number of cases $=2822$, Total RTA cases $=1291$

\begin{tabular}{|c|c|c|c|c|c|}
\hline $\begin{array}{c}\text { Sr. } \\
\text { No. }\end{array}$ & $\begin{array}{c}\text { Cases } \\
\text { N=1291 }\end{array}$ & $\begin{array}{c}\text { Mild } \\
\text { (GCS 13- } \\
\mathbf{1 5} \text { ) } \\
\mathbf{N = 6 1 0}\end{array}$ & $\begin{array}{c}\text { Moderate } \\
\text { (GCS 9-12) } \\
\mathbf{N = 2 8 1}\end{array}$ & $\begin{array}{c}\text { Severe } \\
\text { (GCS 3-8) } \\
\mathbf{N = 4 0 0}\end{array}$ & $\begin{array}{c}\text { Total } \\
\mathbf{N = 1 2 9 1}\end{array}$ \\
\hline 1. & $\begin{array}{c}\text { Two- } \\
\text { wheeler } \\
\text { occupants }\end{array}$ & $\begin{array}{c}385 \\
(58.7 \%)\end{array}$ & $\begin{array}{c}110 \\
(16.8 \%)\end{array}$ & $\begin{array}{c}160 \\
(24.4 \%)\end{array}$ & $\begin{array}{c}655 \\
(50.7 \%)\end{array}$ \\
\hline 2. & $\begin{array}{c}\text { Four- } \\
\text { wheeler } \\
\text { occupants }\end{array}$ & $\begin{array}{c}115 \\
(28.9 \%)\end{array}$ & $98(24.6 \%)$ & $\begin{array}{c}185 \\
(46.5 \%)\end{array}$ & $\begin{array}{c}398 \\
(31 \%)\end{array}$ \\
\hline 3. & $\begin{array}{c}\text { Pedestrians } \\
110 \\
(46.2 \%)\end{array}$ & $73(30.6 \%)$ & $\begin{array}{c}55 \\
(23.1 \%)\end{array}$ & $\begin{array}{c}238 \\
(18 \%)\end{array}$ \\
\hline \multicolumn{7}{|c|}{ Table 6. Severity of RTA cases according to GCS Score at } \\
Time of Admission
\end{tabular}

Total number of cases $=2822$

\begin{tabular}{|c|c|c|}
\hline $\begin{array}{c}\text { Sr. } \\
\text { No. }\end{array}$ & Associated Injuries & $\begin{array}{c}\text { Head Injury Cases } \\
\text { (n=2822) }\end{array}$ \\
\hline 1. & Upper limb fractures & $350(12.4 \%)$ \\
\hline 2. & Lower limb fractures & $286(10.13 \%)$ \\
\hline 3. & $\begin{array}{c}\text { Chest trauma (haemothorax, } \\
\text { pneumothorax, pleural effusion) }\end{array}$ & $244(8.64 \%)$ \\
\hline 4. & $\begin{array}{c}\text { Abdomen (blunt trauma, } \\
\text { penetrating trauma) }\end{array}$ & $120(4.25 \%)$ \\
\hline 5 & $\begin{array}{c}\text { Spine (Injury to cervical, lumbar, } \\
\text { dorsal and sacral spine) }\end{array}$ & $90(3.18 \%)$ \\
\hline \multicolumn{3}{|c|}{ Table 7. Cases with associated Injuries } \\
in Addition to Head Injury
\end{tabular}

Upper limb fractures are the most common injuries associated with head injury cases that are $12.4 \%$ followed by lower limb fractures accounted for $10.13 \%$. Spine injuries were found only in $3.18 \%$ of cases. Chest trauma was present in $8.64 \%$ cases followed by abdominal injury cases sharing $4.25 \%$ with the total number.

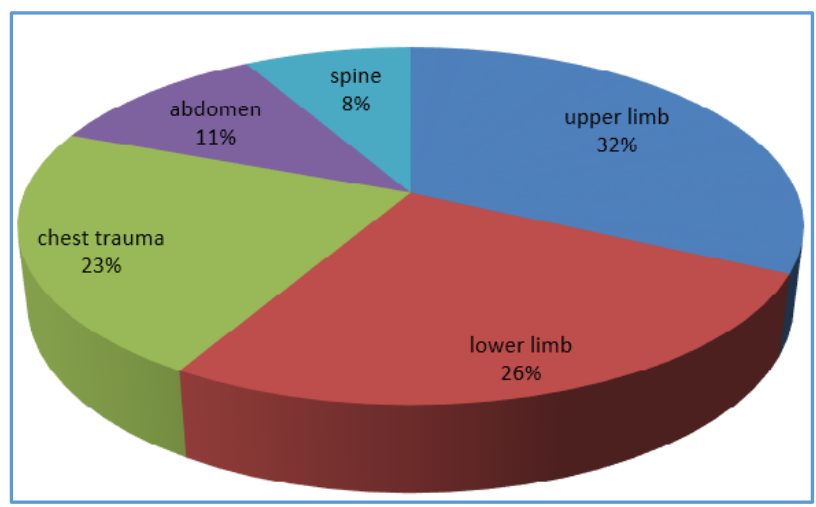

Total number of cases $=2822$; Total number of deaths $=$ 388 (13.7\%); Total number of cases with good recovery= 2366 (83.8\%); Total number of cases with unknown outcome $=68(2.5 \%)$.

\begin{tabular}{|c|c|c|c|c|}
\hline $\begin{array}{c}\text { Sr. } \\
\text { No. }\end{array}$ & Cases & $\begin{array}{c}\text { Severe Head } \\
\text { Injury } \\
\text { Group (<8) }\end{array}$ & $\begin{array}{c}\text { Moderate Head } \\
\text { Injury Group } \\
\text { (9-12) }\end{array}$ & $\begin{array}{c}\text { Mild Head } \\
\text { Injury Group } \\
(\mathbf{1 3 - 1 5 )}\end{array}$ \\
\hline 1. & $\begin{array}{c}\text { Cases during } \\
\text { admission } \\
\mathrm{n}=2822\end{array}$ & $\begin{array}{c}844 \\
(29.9 \%)\end{array}$ & $\begin{array}{c}413 \\
(14.6 \%)\end{array}$ & $\begin{array}{c}1565 \\
(55.4 \%)\end{array}$ \\
\hline 2. & $\begin{array}{c}\text { Cases during } \\
\text { discharge } \\
\mathrm{n}=2366\end{array}$ & $\begin{array}{c}151 \\
(6.3 \%)\end{array}$ & $\begin{array}{c}255 \\
(10.7 \%)\end{array}$ & $\begin{array}{c}1960 \\
(83 \%)\end{array}$ \\
\hline 3. & $\begin{array}{c}\text { Death } \\
\mathrm{n}=388\end{array}$ & $\begin{array}{c}268 \\
(69 \%)\end{array}$ & $\begin{array}{c}120 \\
(31 \%)\end{array}$ & 0 \\
\hline \multicolumn{4}{|c|}{ Table 8. Evaluation of Outcome } \\
\hline
\end{tabular}

Total number of cases $=2822$

\begin{tabular}{|c|c|c|c|c|}
\hline Sr. No. & Causes of Injury & Cases & Deaths & \% \\
\hline 1. & RTA & 1291 & 191 & $14.7 \%$ \\
\hline 2. & Fall from height & 695 & 74 & $10.6 \%$ \\
\hline 3. & Assaults & 702 & 86 & $12.5 \%$ \\
\hline 4. & Others & 134 & 37 & $27.6 \%$ \\
\hline
\end{tabular}

Table 9. Mortality in Relation to causes of Head Injury 


\section{DISCUSSION}

Such an extensive study of this large database pertaining to Neurotrauma has never been performed in this entire region (Malwa and adjacent region of different states). This study has done an in-depth analysis of prevalence of head injury, its various causes, availability of treatment facilities and outcome in terms of mortality. The study is based on retrospective collection of inpatient's hospital data. Inadequacy of hospital records because of lack of proper maintenance of records, patients get absconded, records are sent to courts etc. are major obstacles in clearly defining the underestimation of the actual magnitude of the issue raised in this study.

At the global level, it is estimated that the annual incidence of Traumatic Brain Injuries (TBIs) is 200 per $1,00,000$ per year and mortality is 20 per $1,00,000$ per year. 1 The epidemiological study undertaken in Bangalore has revealed that the incidence was $150 / 1,00,000$, mortality rate was $20 / 1,00,000$ and case fatality rate was $10 \%$ respectively.2,3

\section{Year Wise Distribution of Head Injury Cases and their Aetiology}

In the present study, it is obvious that the cases of neurotrauma getting admitted at MYH are steadily increasing. Although, the total number of cases due to RTA are seen to be increasing; however, the epidemiological distribution as assault RTA fall etc. show little variation. This may be because of the selection bias, as this is a study based on the admissions to a single hospital.

In our study, $45.8 \%$ patients were victims of road traffic accidents followed by $24.6 \%$ cases due to fall from height and $24.6 \%$ due to assault. In the study by NIMHANS, 4 the incidence of Road Traffic Injuries was $59 \%$ followed by falls (25\%) and Violence (10\%). The findings of the present study are almost consistent with the study by NIMHANS, except that more than double incidence of assault and violence is noticed.

1291 patients of head injury were victims of RTA. Of these $51 \%$ were occupants of two wheelers, 31\% were four wheelers and $18 \%$ were pedestrians. The four wheelers occupants of $81 \%$ had moderate-to-severe head injury, $79 \%$ of two-wheeler occupants had moderate-to-severe injury.

\section{Age and Sex Distribution}

The head injury victims between the ages of 21 and 40 years accounted for $46.7 \%$ of all. The overall male-female ratio was $5: 1$. The highest difference in sex ratio was observed in the age group of 11 years to 40 years on an average of 8:1. This may be because of aggressive behaviour, employment related outdoor activities and use of vehicles. In comparison to 2005 NIMHANS study, ${ }^{4}$ the incidence of head injury patients was highest in age group of 21 - 35 years approximately $40 \%$ with male-to-female ratio of $4: 1$.

\section{Duration of Presentation of Cases}

In this study, about $56 \%$ of the total cases treated were transferred from other hospitals and 44\% were brought directly for treatment and were admitted.

Our study also reveals that around $47.5 \%$ of the patients could reach MYH within 4 hours of injury. About $25.2 \%$ of the patients presented within $4-12$ hours of injury. $16 \%$ patients presented within 12 hours of injury. Only $11.3 \%$ of the patients presented after 24 hours of injury. A delay in admission after 4 hours was more likely due to-

- No help available at the site of injury.

- Travel distance from site of injury to hospital.

- Initial well-being of patient following injury.

In the study conducted by NIMHANS, it was found that $30 \%$ were able to reach within 3 hours.

\section{Classification of Cases according to GCS Score}

Of the total 2822 patients of head injury $55.5 \%$ patients suffered mild head injury, while $44.5 \%$ patients had moderate-to-severe head injury. One reason for admission of large number of cases in mild injury group was as per Government policy, CT scan of below poverty patients (BPL) can be done only after admission. The severity of head injury was similar in all the three years of the study.

$7.8 \%$ of mild head injury still needed emergency neurosurgical intervention. In comparison, $71 \%$ of all patients having moderate-to-severe head injury did not need neurosurgical procedure.

This clearly highlights the fact that even mild head injury patients need observation and may need referral to a suitable neurosurgical centre, whereas majority of patients with moderate-to-severe head injury could also be managed at nearest urban and rural centres with ICU care setup. However, they still require opinion and consultations from neurosurgeons to optimise their management.

In the study conducted by NIMHANS the incidence of injury found was $71 \%$ of TBIs were mild, $15 \%$ moderate and $13 \%$ severe in nature based on Glasgow Coma Scale.

\section{Head Injury and Alcohol Consumption}

Patients or relatives who admitted the history of alcohol consumption before trauma are included in the study. No tests were performed to confirm in other cases; hence, it is likely that the incidence of alcohol will be much higher than the present figure of $13 \%$ in the age group more than 11 years $(n=2432)$.

\section{Neurosurgical Intervention}

Neurosurgical interventions which were done in this study includes elevation or excision of depressed fractures causing mass effect or lacerating the brain parenchyma, evacuation of haematoma (EDH SHD Parenchymal bleed) and decompressive craniectomy in the absence of haematoma as a life-saving emergency. Tracheostomy and other surgical interventions for management have not been taken into account.

Of the total 2822 cases $479(16.97 \%)$ patients needed neurosurgical intervention, while 2343 patients were managed non-operatively. Of the 1565 patients with the GCS of $13-15,122$ (7.8\%) needed neurosurgical intervention, highlighting the importance of CT scan evaluation in this subset of seeming less severe head injury patients. There were 413 patients with moderate head injury (GCS 9 - 12), of which 128 (31\%) underwent a neurosurgical intervention. Of the 844 patients with severe head injury (GCS 8 and below), $229(27 \%)$ needed neurosurgical intervention. This study reveals that close to $70 \%$ patients with moderate and severe 
head injury were managed without neurosurgical interventions in intensive care.

Even a normal GCS does not rule out the need for surgery and $7.8 \%$ of mild head injury required surgical intervention. Hence, role of CT scan is important in these subsets of patients.

The most common procedure done was depressed fracture excision/ elevation.

\section{Trends in Road Traffic Accidents}

In the study of 2822 cases Road Traffic Accidents accounted for 1291 cases, $51 \%$ were two-wheeler occupants, $31 \%$ were four-wheeler occupants and $18 \%$ were pedestrians. $71 \%$ of four-wheeler occupants suffered moderate-to-severe head injury, whereas $41.2 \%$ of two-wheeler occupants suffered moderate-to-severe head injury. Even the pedestrians were not safe, as more than $50 \%$ suffered moderate-to-severe head injury.

This pattern clearly highlights that there is a clear breach of safe driving practice on roads. The severity of trauma in all these patients can be significantly reduced by strict enforcement of safety measures like separate lanes for pedestrians and two wheelers provision of zebra crossings and proper traffic signal posts to facilitate pedestrians.

The incidence of severity in two-wheeler occupants can be significantly reduced by mandatory use of helmets and speed limit restrictions.

Similarly, the severity of four-wheeler occupants can be reduced by use of seat belts and restricting speeds. In all groups, the prevalence and severity of trauma can be curtailed if drunken driving can be strictly controlled.

\section{Associated Injuries}

In the present study, it was found that upper limb injury like fractures was found in $12 \%$ of the cases, lower limb injury was found in $10 \%$ cases, chest injury was found in $8.7 \%$, abdominal injury was found in $4.3 \%$ and spine involvement was found in $3.75 \%$.

\section{Outcome of Cases at Time of Discharge}

The actual parameter for assessing outcome of patients at the time of discharge is Glasgow Outcome Scale. But the present study being a retrospective one and fallacies on record maintenance, the outcome of cases could not be assessed properly.

The GCS score was recorded at time of admission as well as discharge, which has given a crude idea about outcome. About $83.8 \%$ patients were discharged.

MY hospital being a public-sector hospital maintains a policy to discharge the patients till stability of condition and therefore a discharge card is given as indirect evidence of relative well-being of the patient.

\section{CONCLUSION}

The incidence of head injury cases has increased in last three years as per this study. The most susceptible age group is 21 to 40 years with RTA as the major cause. Fall from height is the most common mode of injury in the first decade of life.

The highest difference in sex ratio was observed in 11 to 40 years of age (8:1), which is a reflection of the aggressive behaviour and work culture in the society where males are required to frequently travel by personal vehicles.
The severity of head injury can be reduced by enforcing existing traffic rules strictly, which includes use of helmets for two wheelers and safety seat belts for four wheelers and setting speed limits. The facility for safety of pedestrians has to be improved by provision of separate lanes and zebra crossings and traffic signal posts.

The impact of alcohol intake on head injury incidence is under-reported in this study, but is a significant contributory cause of head injury.

Lack of diagnostic and basic treatment facilities in outskirts lead to referral of large number of mild head injury patients to MYH, which over burdens the limited resources at MYH.

$7.8 \%$ of mild head injury still needed emergency neurosurgical intervention. In comparison, $71 \%$ of all patients having moderate-to-severe head injury did not need neurosurgical procedure. This clearly highlights the fact that even mild head injury patients need observation and may need referral to a suitable neurosurgical centre, whereas majority of patients with moderate-to-severe head injury could also be managed at nearest urban and rural centres with ICU care setup. However, they still require opinion and consultations from neurosurgeons to optimise their management. These issues need to be addressed by developing trauma units equipped with CT scan facility in existing urban and rural health centres.

There is a need to develop MYH as a tertiary neurotrauma centre to facilitate optimum management of severe head injury patients and ensure training of manpower for smooth functioning of peripheral trauma centres.

\author{
Abbreviations \\ \# - Fracture. \\ C - Comminuted \\ EDH - Extradural haematoma. \\ SDH - Subdural haematoma. \\ SAH - Subarachnoid haematoma. \\ F - Frontal. \\ P - Parietal. \\ O - Occipital. \\ $\mathrm{T}$ - Temporal. \\ STI - Soft tissue injury. \\ WNL - Within normal limit. \\ D - Depressed. \\ MYH - Maharaja Yeshwantrao Hospital. \\ RTA - Road traffic accidents.
}

\section{REFERENCES}

[1] Romer CJ, Zitnay G, Gururaj G. Prevention, critical care and rehabilitation of Neurotrauma. WHO Collaborating Centre for Neurotrauma 1995.

[2] Gururaj G. An epidemiological approach to prevention - prehospital care and rehabilitation in neurotrauma. Neurology India 1995;43(3):95-105.

[3] Gururaj G. Epidemiology of traumatic brain injuries: Indian scenario. Neurological Research 2002;24(1):24-8.

[4] Gururaj G, Kolluri SVR, Chandramouli BA, et al. Traumatic brain injury. Publication No. 61. Bengaluru 560029, India. National Institute of Mental Health and Neurosciences 2005: p. 17-23. 